\title{
The Reception of Erasmus in the Early Modern Period
}

\author{
Edited by
}

Karl A.E. Enenkel

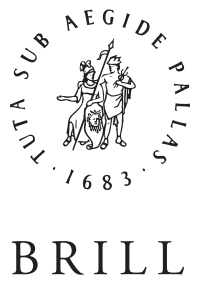

LEIDEN • BOSTON

2013

(C) 2013 Koninklijke Brill NV ISBN 978-90-04-25562-3 


\section{CONTENTS}

Acknowledgements ...................................................................................... vii

Notes on the Editor ............................................................................... ix

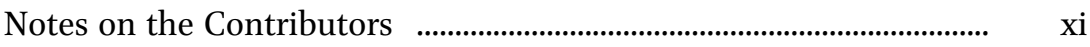



Introduction - Manifold Reader Responses: The Reception of

Erasmus in the Early Modern Europe .................................................

KARL ENENKEL

PART I

HUMANISM

A Blueprint for the Reception of Erasmus: Beatus Rhenanus's

Second Vita Erasmi (1540) ................................................................... $\quad 25$

KARL ENENKEL

Medicinae laus per Eobanum Hessum ex Erasmo, versu reddita

Reassessed

DIRK SACRÉ

PART II

RELIGIOUS IDEAS

Universalism and Tolerance in a Follower of Erasmus from Zurich:

Theodor Bibliander

LUCIA FELICI

'Betwixt Heaven and Hell': Religious Toleration and the Reception of Erasmus in Restoration England GREGORY D. DODDS

(C) 2013 Koninklijke Brill NV ISBN 978-90-04-25562-3 
Praise and Blame: Peter Canisius's Ambivalent Assessment of Erasmus

Hilmar M. PABEL

PART III

POLITICAL IDEAS:

IRENISM AND MIRROR OF A CHRISTIAN PRINCE

Erasmian Irenism in the Poetry of Pierre de Ronsard 163 PHILIP FORD $\dagger$

On Good Government: Erasmus's Institutio Principis Christiani versus Lipsius's Politica

JEANINE De LANDTSHEER

PART IV

RABELAISIAN SATIRE, TRIUMPH, DIALOGUE AND OTHER ADAPTATIONS: RECEPTIONS OF THE PRAISE OF FOLLY IN FRENCH, ITALIAN AND DUTCH LITERATURE

Jean Thenaud and François Rabelais: Some Hypotheses on the Early Reception of Erasmus in French Vernacular Literature ..... 211 PAUL J. SMITH

Antonio Brucioli and the Italian Reception of Erasmus: The Praise of Folly in Dialogue 237 REINIER LEUSHUIS

Erasmus and the Radical Enlightenment: An Atheistic Adaptation of The Praise of Folly by Jan van der Wyck (1798) 261 JOHANNES TRAPMAN

Index Nominum 273

(c) 2013 Koninklijke Brill NV ISBN 978-90-04-25562-3 


\title{
ON GOOD GOVERNMENT: \\ ERASMUS'S INSTITUTIO PRINCIPIS CHRISTIANI \\ VERSUS LIPSIUS'S POLITICA*
}

\author{
Jeanine De Landtsheer
}

\section{A General Introduction to Both Treatises}

\subsection{Erasmus}

In 1515 Jean le Sauvage, Lord Chancellor of Brabant, proposed to appoint Erasmus councillor of the adolescent Charles V. One year later this proposal was accepted, although it was, in fact, no more than a honorary title involving an annuity of two-hundred guilders. In May of that same year Johann Froben published Erasmus's Institutio Principis Christiani, a treatise dedicated to the young sovereign on the occasion of his accession to the throne of Aragon [Fig. 1]. ${ }^{1}$ According to the author's letters of that time, it had taken him more than a year to finish the treatise. He did not so much vent his political ideas, but rather present them as part of what was first and foremost conceived as a pedagogical treatise. At the same time Erasmus published by way of introduction a translation of pseudoIsocrates, On kingship, addressed to King Nicocles of Salamis, a translation of Plutarch's essay On the Importance of Philosophers to Men in Power (= Moralia 776a-779c), ${ }^{2}$ and a reissue of the Panegyric for Archduke Philip of Austria, an oration he had delivered when Charles V's father, Philip the Fair, returned to the Low-Countries from Spain at the end of 1503 (the text is dated 6 January 1504).

* For the proofreading of my English, I am greatly indebted to Charles Fantazzi. Chris Heesakkers kindly accepted to read the penultimate version and offered some useful suggestions. Adrie vander Laan (Curator of the Erasmiana at Rotterdam, Municipal Library), Anton van der Lem (Curator of the Rare Book Department at Leiden UB) and Katrien Smeyers (Curator of the Rare Book Department at Leuven UB) allowed me to publish the illustrations.

1 Cf. Herding O. (ed.), ASD IV.1 (Amsterdam: 1974) 95-219; The education of a Christian Prince, translated by Neil M. Cheshire and Michael J. Heath, Collected Works of Erasmus (henceforth CWE) 27 (Toronto-Buffalo-London: 1986) 199-288, and reprinted together with Panegyric for Archduke Philip of Austria, translated by Lisa Jardine, Cambridge Texts in the History of Political Thought (Cambridge: 1997).

2 Sc. Maxime cum principibus philosopho esse disserendum (Moralia 776a-779c).

\section{(C) 2013 Koninklijke Brill NV ISBN 978-90-04-25562-3}




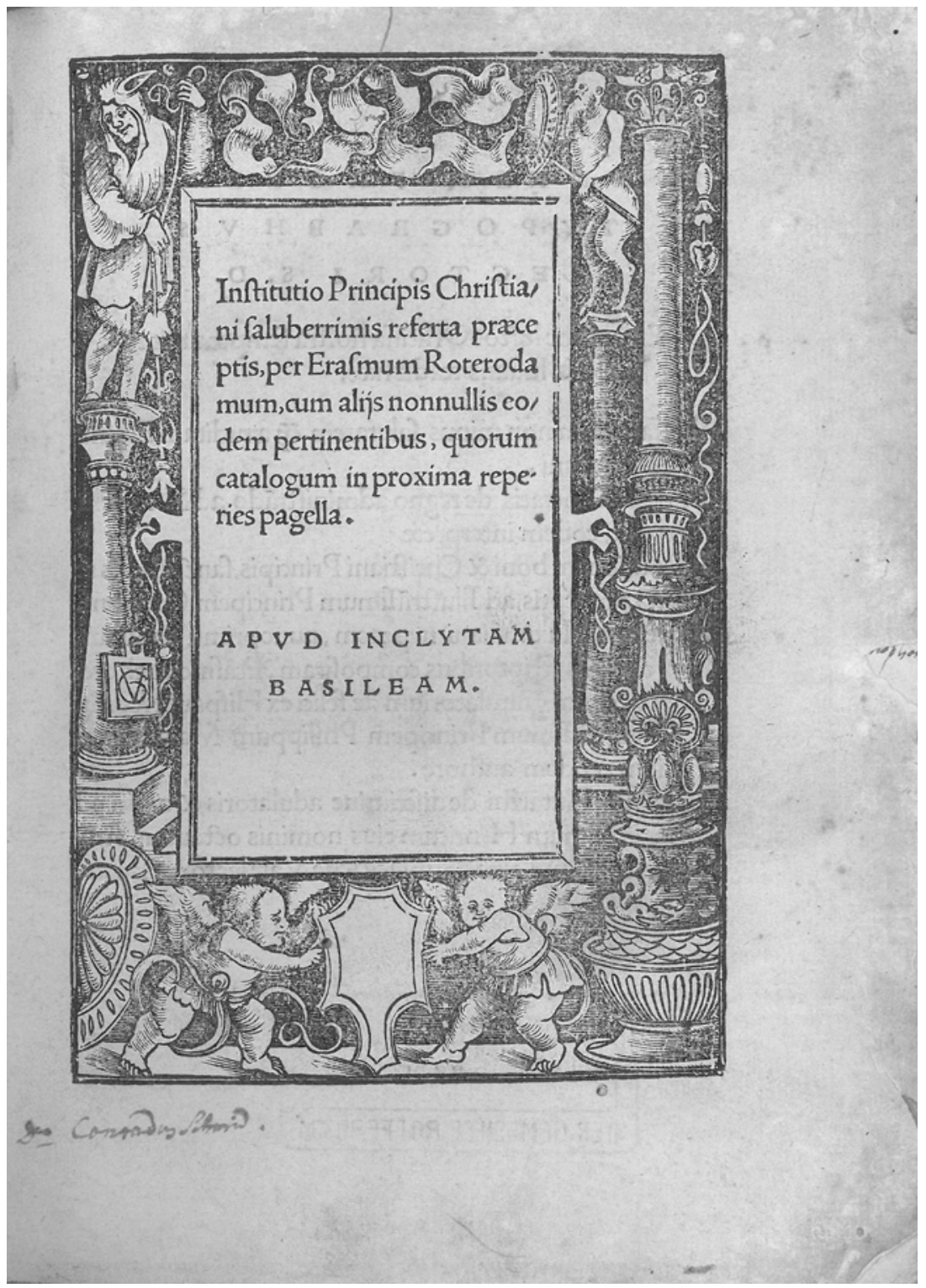

Figure 1. Title page of the editio princeps of Erasmus, Institutio principis Christiani (Basle, Johann Froben: 1516). Rotterdam Municipal Library, 2D3.

(C) 2013 Koninklijke Brill NV ISBN 978-90-04-25562-3 
In the first chapter of his treatise, which is slightly longer than the next ten chapters together, Erasmus helps the future prince grow from early childhood into a virtuous adult who, to quote Lisa Jardine, 'needs to be educated so as to recognise and pursue the morally good in all things, in order to be able to take decisions correctly on behalf of his people'. ${ }^{3}$ Jardine does not mention here the point of view omnipresent throughout the Institutio principis Christiani, namely that a virtuous man and a wise and just ruler is ipso facto a good Christian. In the second half of his treatise Erasmus endeavours to paint a portrait of an exemplary ruler. In ten, much shorter chapters he dwells in a more practical way on various aspects of good government, a brief catalogue, in fact, of a sovereign's duties elucidated by useful suggestions of what a competent prince ought either to strive after or to avoid, often worked out by contrasting a true and honourable prince against a tyrant.

Despite the explicit reference to Isocrates, Erasmus found the inspiration for his ideal Prince also in Plato, as is proven by numerous quotations or paraphrases borrowed from either the Republic or the Laws. Aristotle's Politics as well was a useful source, together with Xenophon's Oeconomicus and Plutarch's essay To an Uneducated Ruler (= Moralia 779d-782f). Among the Latin authors, he made use of Seneca, especially of his On clemency, addressed to the young Nero, and Cicero's On duties. ${ }^{4}$

To avoid the descriptive, continuous, and often somewhat dull line of argument of a theoretical treatise, he preferred to put forward his ideas in a somewhat haphazard succession of thoughts, reminiscent of Seneca's Letters to Lucilius. Thus the reader is guided through a chain of mostly short paragraphs full of repetition and antithesis between what ought or ought not to be done, the whole illustrated by a plethora of aphorisms and numerous anecdotes about sovereigns from Antiquity. In the subtitle Erasmus described his method as 'aphorismis digesta quo minus onerosa sit lectio' ('divided into short, pithy sentences to make the reading less boring'). To embellish his argumentation and to make it more lively, numerous quotations and anecdotes were added. For the latter the biographies written by Diogenes Laërtius, Plutarch, Suetonius, and the authors of the Historia Augusta were a welcome source. Moreover, Erasmus also drew from his own publications, by using a number of sententiae

\footnotetext{
3 Jardine, The Education of a Christian Prince vii-viii.

4 Cicero's De re publica was only known via quotations in other authors; it was partially discovered in 1820 .
}

\section{(C) 2013 Koninklijke Brill NV ISBN 978-90-04-25562-3}


commented upon some years before in his Adagiorum Chiliades (Venice, Aldus Manutius: 1508).

\subsection{Lipsius}

About seventy-five years later Justus Lipsius dedicated his Politica sive civilis doctrinae libri sex in a more general way to the Emperor, Kings and Princes (Imperator, Reges, Principes). This is also the reason why this letter has not been included in the appropriate volume of the Iusti Lipsi Epistolae. ${ }^{5}$ From the mid-1580s onwards, Lipsius's correspondence shows an increasing apprehensiveness of the changes in the political and religious climate of the Northern Netherlands, which led to a first, unsuccessful attempt of returning to his native country in 1586, after having taught at Leiden University from April 1578 onwards. It was probably during this journey that he conceived the idea of writing a treatise on statesmanship, to form a kind of philosophical diptych with his De Constantia libri duo. Qui alloquium praecipue continent in publicis malis, published by Christopher Plantin in Leiden in $1584{ }^{6}$ To quote Jan Waszink in the introduction to his recent edition: 'It is Lipsius' explicit aim to provide a discussion of government which is generally and universally valid. At the same time the Politica is strictly practical. All theoretical debates of moral and political philosophy stay in the background, and Lipsius does not explicitly answer or react to existing theories'. ${ }^{7}$

5 Sc. Iusti Lipsi Epistolae, pars III: 1588-159o, ed. S. Sué and H. Peeters (Brussels: 1987). The letter will nevertheless be included in the final volume of the series, ILE XIX. See also the facsimile edition of the English translation by William Jones, Sixe Bookes of Politickes or Civil Doctrine, written in Latine by Iustus Lipsius, which doe especially concerne Principalitie (London, Richard Field for William Ponsonby: 1594), The English Experience 287 (Amsterdam-New York: 1970) and its most recent edition Justus Lipsius, Politica. Six Books of Politics or Political Instruction. Politicorum sive Civilis Doctrinae libri sex, edited, with translation and introduction by J. Waszink, Bibliotheca Latinitatis Novae 5 (Assen: 2004). Lipsius's political thought and its influence on Neostoic political theory, especially within the German Empire, has been extensively studied by Gerhard Oestreich, cf. a survey of his ideas and bibliographical references in Waszink (ed.), Lipsius, Politica 10-14.

${ }^{6}$ In the Ad lectorem of his Politica, Lipsius states: 'Quod nunc tibi damus, Politica esse vides; in quibus hoc nobis consilium, ut quemadmodum in ConstaNTIA cives formavimus ad patiendum et parendum, ita hic eos qui imperant ad regendum' - 'The work which I now present to you, is on Politics, as you see. It is my purpose, just as in De CONSTANTIA I equipped citizens to endurance and to obedience, to equip men in power for governing' (translation slightly altered from Waszink [ed.], Lipsius, Politica 231).

7 Waszink (ed.), Lipsius, Politica 81.

\section{(C) 2013 Koninklijke Brill NV ISBN 978-90-04-25562-3}


In January 1587 , hardly two months after his return to Leiden, Lipsius was gathering source material for his new treatise, as he informed one of his correspondents, ${ }^{8}$ but the fact that Prince Maurice appointed him rector of the University in February 1587 and again in 1588, certainly slowed down his writing. The treatise was printed as an in-quarto by Franciscus Raphelengius in Leiden and appeared in early August 1589 [Fig. 2]. Still that same year a cheaper in-octavo edition was available. ${ }^{9}$ By the summer of 1590 Raphelengius had run out of copies and published a second inoctavo edition, with a considerable number of (minor) corrections, which was available from August onwards, in time for the autumn book fair at Frankfurt. The specification 'quam auctor pro germana et fida agnoscit' ('acknowledged by the author as authentic and true') added to the title was to warn off possible readers of purchasing the cheap and sloppily printed edition, presented by the Frankfurt publishers Johann Wechel and Peter Fischer at the spring book fair of that same year [Fig. 3].$^{10}$

Although the pedagogical concern of raising a young prince into a harmonious and virtuous adult, which is the subject of the first half of Erasmus's Institutio Principis Christiani, is entirely absent in the Politica, Lipsius's

8 Cf. ILE III, $870103 \mathrm{C}$ to Theodorus Canterus in Utrecht: 'Nos sumus in politicis quibusdam colligendis e Taciti et plurium scriptis' - 'We are making excerpts of texts about politics from the writings of Tacitus and several others'. The text tradition of Lipsius's Politica has been discussed at length by Waszink (ed.), Lipsius, Politica $165^{-198}$ (= chapter six). I am not at all convinced, though, that Lipsius really 'started writing the Politica when he was away from Leiden in October 1586 and travelling in northern Germany', as Waszink states (quot. p. 165 - my italics; the statement is repeated elsewhere). As we will see, the way Lipsius conceived his treatise was far too complicated for him to be working on it while he was in the middle of nowhere, without a good library at his disposal. Moreover, the letter to Canterus clearly shows that he was setting out to gather his material only two months later.

9 The first, fully dated covering letter is ILE III, 8908 10 to Carolus Clusius. Lipsius's Politica was being printed when Plantin died on 1 July 1589 . See on this first edition Vander Haeghen F. - Lenger M.-T., Bibliotheca Belgica: Bibliographie générale des Pays-Bas, 6 vols. (Brussels: 1964-1975), vol. III, 1040-1041, L-428 [henceforth abbreviated as BBr] and Voet L. Voet-Grisolle J., The Plantin Press, 1555-1589: a Bibliography of the Works printed and published by Christopher Plantin at Antwerp and Leiden, 6 vols. (Amsterdam: 1980-1983), vol. III. Cf. also Die Messkataloge Georg Willers. IV: Fastenmesse 1588 bis Herbstmesse 1592 (Hildesheim-New York: 1978) 208.

10 On Raphelengius's 1590 edition, see $\mathrm{BBr}$ vol. III, 1042, L-431 (= Die Messkataloge 316 ). On the unauthorized editions of Lipsius's Politica published by Johann Wechel and Peter Fischer in 1590-1591, see BBr, vol. III, 1042, L-430 (= Die Messkataloge Georg Willers 262) and BBr vol., III, 1043, L-433 (1591, not in Die Messkataloge Georg Willers) respectively; De Landtsheer J., "An author and his Printer: Justus Lipsius and the Officina Plantiniana”, Quaerendo 37 (2007) 10-29 (especially 17-22). On 1 August 1592 Emperor Rudolph II granted Lipsius a privilege assuring the protection of any new work or edition published by the printer of his choice for a duration of thirty years.

\section{(C) 2013 Koninklijke Brill NV ISBN 978-90-04-25562-3}




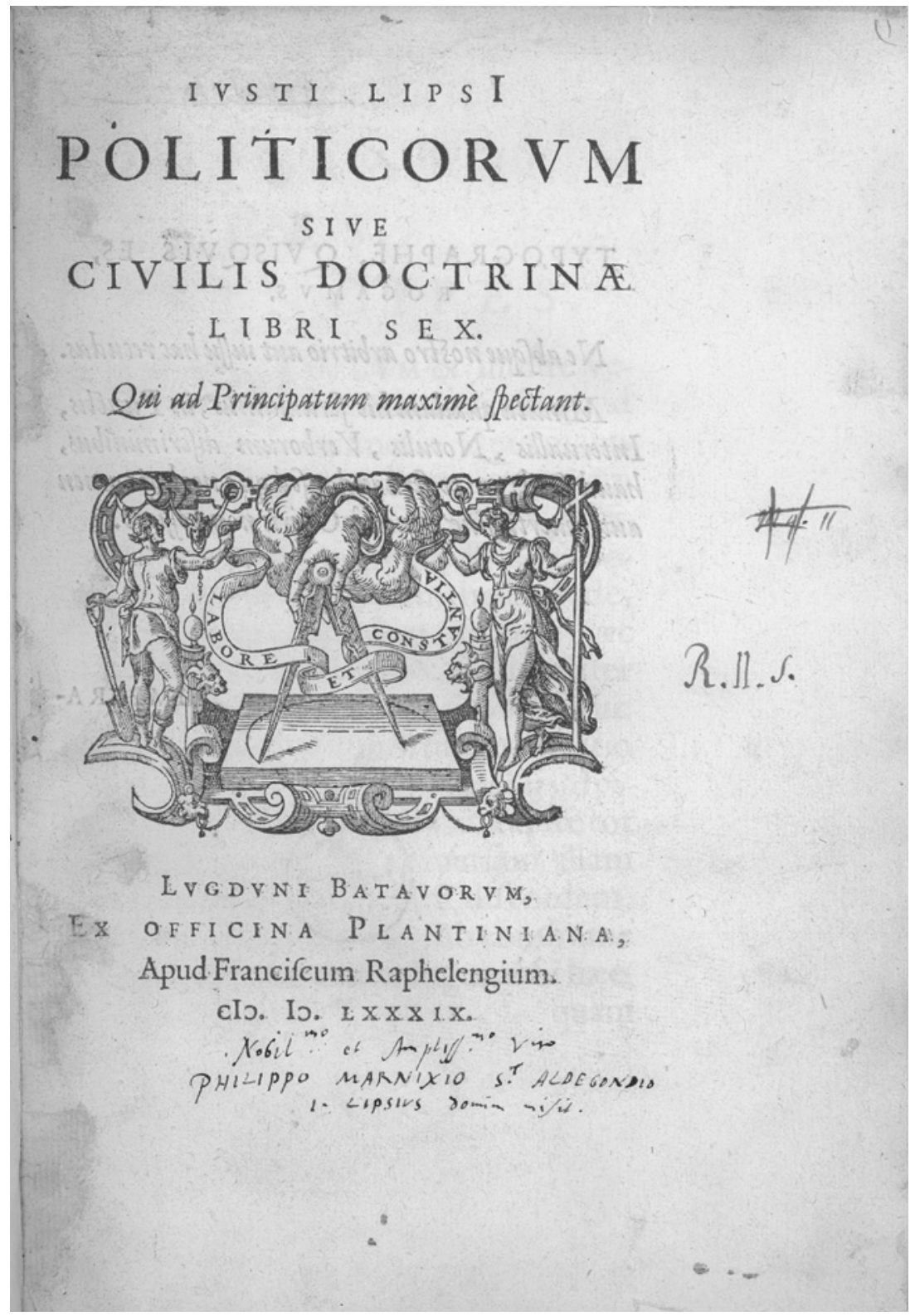

Figure 2. Title page of the editio princeps of Lipsius's Politica with autograph dedication to Philip Marnix of Sint Aldegonde: 'Nobilissimo et Amplissimo viro, Philippo Marnixio St. Aldegondio, I[ustus] Lipsius donum misit'. Leiden, University Library, 759 C 75:1.

(C) 2013 Koninklijke Brill NV ISBN 978-90-04-25562-3 


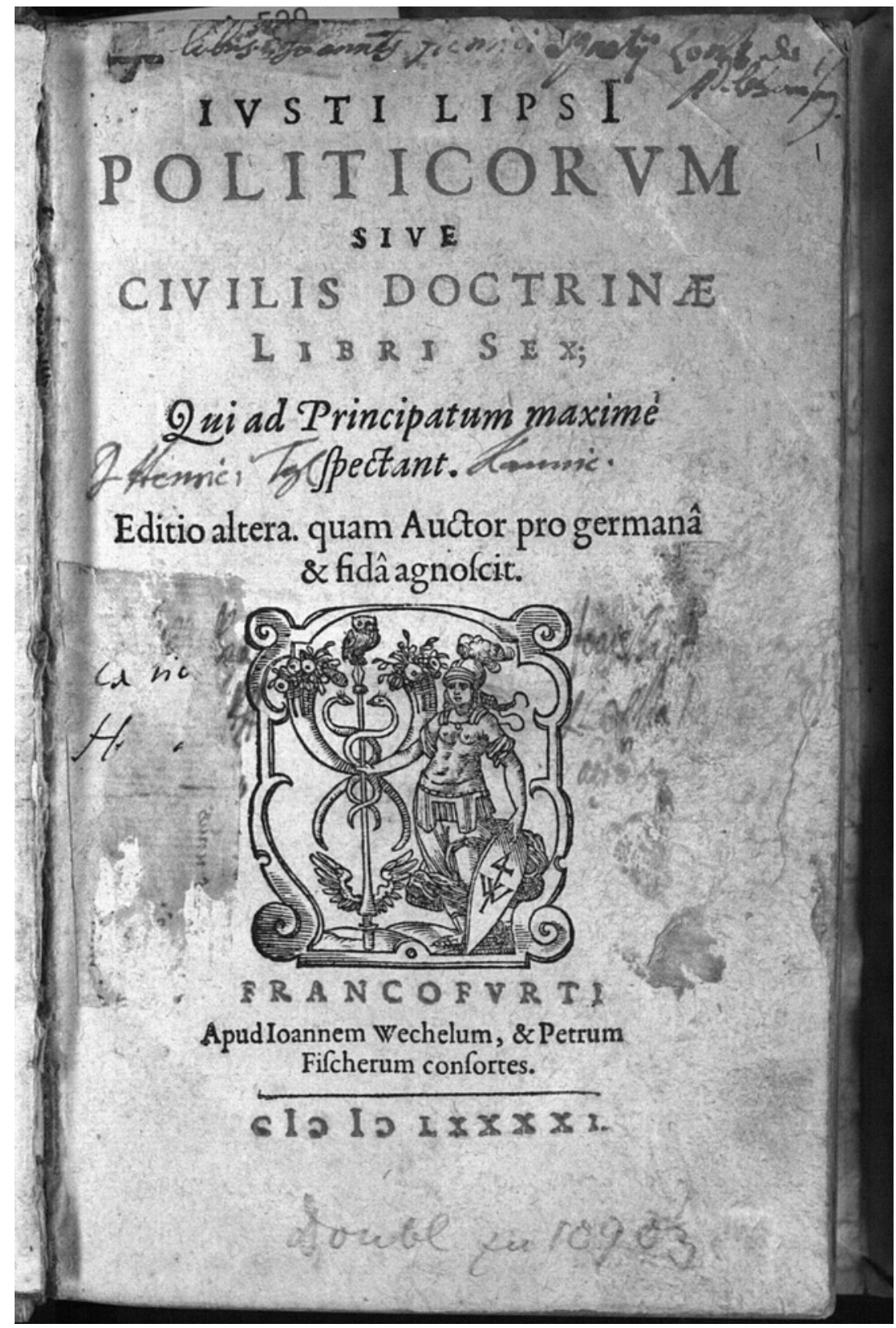

Figure 3. Title page of the pirate edition (Frankfurt, Fischer - Wechel: 1591). Leuven, University Library, BRES, CaaA529.

(C) 2013 Koninklijke Brill NV ISBN 978-90-04-25562-3 
treatise can nevertheless be divided into two similar parts. In books 1 and 2 the author focuses on Virtus and Prudentia (virtue and personal wisdom) as praiseworthy and necessary assets of any honourable man, which will win a ruler credibility and respect. As is the case with Erasmus, this general portrait endorses entirely the ideas promoted by traditional Ciceronian, Stoic, and Christian morality. In the second part Lipsius switches to the public aspect of Prudentia as the main requisite for statecraft. After dealing in book three with the qualities to be expected from the prince's staff, he puts forward, in books four to six, his views on propria Prudentia, the political perception of the ruler himself, as a guarantee for a successful government, with special attention to the relation between State and Religion, the prince's attitude towards both external and civil war, and, consequently, the need for and the demands of a well organized army.

As is always the case in Lipsius's writings, the dedicatory letter is followed by a preface Ad lectorem, explaining the purpose of his work and other particulars, besides giving some advice about how the reader should proceed. As already pointed out, Lipsius wanted his reader to see the Politica as a continuation of his De constantia, but directed at sovereigns, their assistants or, in case of a young man, their humanist teachers, and by extension addressing whoever had a leading and responsible task in court, army, society, or church. Readers, who were thoroughly familiar with Latin and had sufficient knowledge of political theories were welcomed as well. Lipsius acknowledged that others before him had written about government and statecraft, Plato and Aristotle in particular, but they had discussed all forms of government in a more general way, whereas he wanted to concentrate on monarchy, as was done by Xenophon, albeit in a limited and not wholly clear way, and based on ancient or barbarian examples. He did not select more recent authors, ${ }^{11}$ although he cautiously admitted his admiration for the sharp intellect of Niccolò Machiavelli, who was immediately criticized for not urging his Prince to follow the path leading towards Virtue and Honor. The most important part of this preface, though, is Lipsius's explanation of how he conceived his work:

For I have applied a rather unexpected kind of style, so that I could truly say that everything is mine and nothing. Although the approach of the subject and the composition are mine, the wording and phrasing are gathered in

11 In fact, Erasmus is never mentioned or explicitly referred to, although Lipsius occasionally intertwines his text with one of his Adages.

\section{(C) 2013 Koninklijke Brill NV ISBN 978-90-04-25562-3}


various ways from ancient writers, mostly from historians; that is, in my eyes, from the very source of Statecraft. ${ }^{12}$

He opted, indeed, to present his ideas in the form of a cento, a patchwork of quotations from a wide range of ancient, but also early-Christian authors - mainly Latin, but occasionally also Greek, albeit always with a Latin translation added. These citations and sententiae he composed into a coherent text by adding his own phrases and fitting the whole into a strict framework of definitions and references to the main line of thought. Furtheron in his Ad lectorem Lipsius acknowledged that to fit the quotations smoothly into his text and avoid any mistakes against the Latin he occasionally changed its phrasing somewhat, for instance the case of a noun or the time of a verb.

The efforts of Franciscus Raphelengius and, for reissues from 1596 onwards, Johannes Moretus and his son Balthasar, turned the Politica into a typographical masterpiece as well. By meticulously observing Lipsius's instructions they succeeded in maintaining a clear distinction between his own sentences (in roman and using the whole width of a page) and the quotations (in italics, with an indentation), which almost has the effect of a dialogue between Lipsius's opinion and its confirmation by a much older and approved authority. Source references - author's name, title of the work, and sometimes also the book - are added in smaller characters in the inner margins, whereas in the outer margins keywords

12 'Nam inopinatum quoddam stili genus instituimus, in quo vere possim dicere omnia nostra esse et nihil. Cum enim inventio tota et ordo a nobis sint, verba tamen et sententias varie conquisivimus a scriptoribus priscis, idque maxime ab Historicis; hoc est, ut ego censeo, a fonte ipso Prudentiae Civilis'. Cf. Waszink (ed.), Lipsius, Politica 230; 232 (the translation is mine). After finishing the treatise Lipsius added a number of annotations (Ad libros Politicorum Notae) for a double purpose: to give a clearer definition of what was ambiguous and to elucidate what was obscure. In Notae 1, 1, for instance, he used the following metaphor to explain once more the way he had conceived his work: 'Lapides et ligna ab aliis accipio; aedificii tamen exstructio et forma tota nostra. Architectus ego sum, sed materie varie undique conduxi. Nec aranearum sane textus ideo melior, quia ex se fila gignunt, nec noster vilior, quia ex alienis libamus, ut apes' ('The stones and rafters I have taken from others; the construction and the shape, however, are entirely mine. I am the architect, but I have gathered material in various ways and from everywhere. A spider's web is not necessarily better, because it produces its own threads; nor does my building become inferior, because I have tasted from others, as bees do'). Cf. Waszink (ed.), Lipsius, Politica 722. Waszink did not consider the Notae as a component of the Politica and only published them as an appendix (appendix 2) without translation or comment. Moreover, although he based his modern edition on the 1599 version (cf. 216), he omitted the dedicatory letter (from the 1596 edition onwards) to Johannes Saracenus (Jean Sarazin, 1539-1598), Abbot of St Vaast's in Arras (1577) and Archbishop of Cambrai (1596), without a word of explanation.

\section{(C) 2013 Koninklijke Brill NV ISBN 978-90-04-25562-3}


from the main text or concise definitions or explanations of a term help the reader to keep up with the argumentation. Each chapter is indicated by a title in small capitals and a one-line summary of its contents in italics [Fig. 4]. ${ }^{13}$ In the preliminary part of the Politica, these summaries have been brought together under the heading "Ordo et Index librorum singillatim et capitum" ("The order of and the Index to each of the books and their chapters"). In the main text each succeeding step in the argumentation and the definitions are highlighted by the use of capitals; occasionally a relevant word is emphasized by the use of italics.

Lipsius concluded his introduction by an auctorum syllabus, pointing out that Tacitus was by far the most quoted author, because of his wisdom, his pithy style, and because Lipsius was well acquainted with his

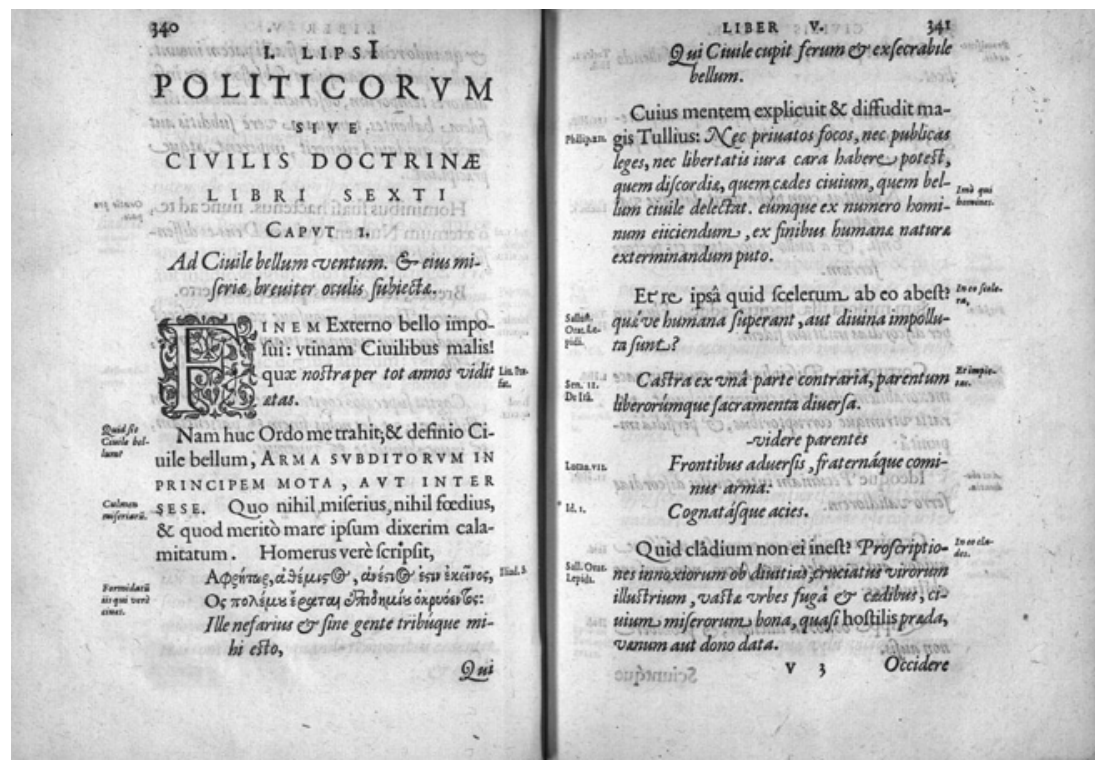

Figure 4. Lipsius, Politica, 6, § 1. Leiden, University Library, 759 C 75:1.

13 On the typical lay-out of the Politica, cf. Moss A., "Vision fragmentée et unitaire: les 'Politiques' et les recueils de lieux communs”, in Mouchel C. (ed.), Juste Lipse (1547-16o6) en son temps. Actes du colloque de Strasbourg, 1994, Colloques, congrès et conférences sur la Renaissance 6 (Paris: 1996) 471-478.

\section{(C) 2013 Koninklijke Brill NV ISBN 978-90-04-25562-3}


work. ${ }^{14}$ It is remarkable that the Roman historian is praised for his sound, political ideas, and not as a master of the dramatic unveiling of hypocrisy, scheming, and intrigue. Other, more frequently quoted Latin authors were Sallust, Livy, Seneca, Cicero, Quintus Curtius, Pliny the Younger, and, concerning military matters, Vegetius; in Greek Aristotle, Plato, Thucydides, and Xenophon are the most quoted. Next follows a whole list of occasionally used sources, mostly Latin, including Biblical books, such as Jeremiah, Proverbs, Acts, the letters of Paul, and Jesus Sirach, or Fathers of the Church, such as Ambrose, Augustine, Lactantius, and Origen. He also mentions Adagia, without an editor's name, but most probably referring to Erasmus's collection.

\section{The Prince as a Good and Virtuous Man}

\subsection{Erasmus's Institutio Principis Christiani, Chapter 1}

The first chapter of the Institutio Principis Christiani was given the title "Nativitas et educatio principis" ("The Birth and Upbringing of a Christian Prince"). Erasmus opens his treatise by pointing out that sovereigns can either be selected by vote or born to the office. Despite his preference for election, a system by which one can take into account the candidate's equability of temperament, his experience, age, and probably also the state of his health, Erasmus accepts the hereditary system as point of departure for his treatise, because it is the most common in his own age. Since most princes simply succeed their fathers, the main hope of getting a good monarch depends on a proper education, which has to start from the very cradle, when the infant's mind is still virgin, unmarked, and undeveloped. As 'nothing makes so deep and indelible a mark as that

14 Lipsius had pubished the Opera omnia of Tacitus in 1574; soon after his arrival in Leiden, a revised edition followed by an extensive commentary to the Annales appeared (1581). Four years later the third, augmented reissue was published, this time with annotations to the Historiae and the Opera minora as well. Further research, as well as the remarks and information sent to him by friends and colleagues from abroad allowed him to publish a supplement to the commentary part, the Curae secundae, in 1588 . The following year Lipsius published not only his Politica, but also a new edition of Tacitus, now with the Curae secundae incorporated in the existing commentary. Cf. De Landtsheer J., "Commentaries on Tacitus by Justus Lipsius. Their Editing and Printing History", in Henderson J.R. (ed.), The Unfolding of Words: Commentary in the Age of Erasmus (Toronto: 2011) [forthcoming]. Waszink (ed.), Lipsius, Politica, counted $5^{28}$ quotations from Tacitus in the Politica, see his survey, 163 .

\section{(C) 2013 Koninklijke Brill NV ISBN 978-90-04-25562-3}


which is impressed in those first years', evil influences have to be kept away and the child imbued with good principles and thoughts. Hence the importance of surrounding the young prince from his early childhood onwards with people of unblemished character, to whose exemplary way of life he can mirror himself, for a royal descent does not guarantee a royal character. Hence also the pre-eminent importance of making a careful selection of the man to whom the education of the future sovereign will be entrusted, for 'a country owes everything to a good prince, but it owes the prince himself to the one whose right counsel has made him what he is.' A teacher who understands his task must be able to reprimand without giving way to abuse, and to praise without giving way to flattery. He must be respected for his disciplined life and liked for his friendly manners. Throughout this first chapter Erasmus is often repeating themes he also develops in the De pueris instituendis, using the same or similar quotations and comparisons in addressing both teachers and parents. In this latter, strictly pedagogical treatise too, he kept accentuating the responsibility of parents towards their children, chiding them for lavishly spending money on the purchase of fields, horses, cattle and dogs, or to the training of these animals. Yet when it comes to the education of their children, the future heirs to their precious possessions, they are always looking for the cheaper solution. ${ }^{15}$ In the Institutio Principis Christiani this becomes:

Principum nonnulli magna cura dispiciunt, quibus equum insignem aut avem aut canem curandum tradunt, nihil autem referre putant, cui filium formandum committant, quem saepenumero talibus credunt praeceptoribus, qualibus nemo plebeius paulo cordatior suos liberos velit concredere. At quid retulerat filium genuisse imperio, nisi eundem cures educandum imperio?

Some princes investigate very carefully who should be entrusted with the care of a prized horse or bird or hound but think it of no importance to whose care they commit the training of a son, and he is very often put in the hands of a sort of teacher whom no ordinary citizen with a little intelligence would want for his children. But what is the point of begetting a son to govern if you do not take care of training him for government?

15 The treatise goes back to Erasmus's sojourn in Italy (1506-1509), but was only completed some twenty years later and published by Jerome Froben and his associates in September 1529. On its genesis, cf. J.-C. Margolin in the "Introduction" to his De pueris statim ac liberaliter instituendis, ASD I.2 (Amsterdam: 1971) 3-7.

${ }_{16}$ Cf. $A S D$ IV.1, 139, l. 90-94; translation Cheshire and Heath, CWE 27, 208; Jardine, The Education of a Christian Prince 8.

\section{(C) 2013 Koninklijke Brill NV ISBN 978-90-04-25562-3}


Moreover, by providing for a proper education for his heir to the throne, the sovereign is already fulfilling an important duty towards his country and achieving praise for himself, for

Nulla pulchrior egregii principis commendatio, quam si talem relinquat reipublicae, ad cuius collationem ipse parum bonus videatur. Nec poterat illius gloria verius illustrari quam sic obscurata.

There is no finer tribute to an excellent prince than when he bequeaths to the state someone by comparison with whom he himself seems ill-qualified, and his glory cannot be more truly illuminated than by being overshadowed in this way. ${ }^{17}$

The future sovereign must grow up into a honourable and virtuous man, who, even in his personal life, will not become involved with activities, aspirations, or pleasures which are popular or still acceptable among ordinary people, but unbecoming for the dignity and the exemplary life expected from a man in a position of authority. He shall always have the welfare of his subjects prevail over his own personal inclinations or advantages. He must learn that his authority and dignity do not depend on outward appearances, such as a long genealogical tree, wealth, glamorous apparel, a train of courtiers, flattering titles, a display of paintings and statues, but on spiritual riches, such as prudence, integrity, fortitude, courage, moderation, and generosity. Erasmus agrees with Plato that a good and wise Prince should be a philosopher as well (if not, he is a tyrant) but at the same time he underlines repeatedly that the king is in fact the image of Christ and his vicar on earth, and that he should model himself on this supreme model, an idea already expressed by Plutarch, To an Uneducated Ruler, 3 (= Moralia, $780 \mathrm{e}-\mathrm{f})$. As Lisa Jardine points out at the end of this first chapter: 'The programme which Erasmus has here outlined is deliberately presented so that it may be appropriately adopted for the education of any boy whose future involves governing the lives of others, i.e. any boy from an elite family'. ${ }^{18}$

17 Cf. ASD IV.1, 138, l. 64-66; translation Cheshire and Heath, CWE 27, 207; Jardine, The Education of a Christian Prince 6-7.

18 Cf. Jardine, The Education of a Christian Prince 54, no. 91.

\section{(C) 2013 Koninklijke Brill NV ISBN 978-90-04-25562-3}




\subsection{Lipsius's Politica, Book 1-2 $2^{19}$}

Lipsius too begins his Politica by discussing the moral qualities that a good and conscientious ruler shares with every honourable man, before turning to more practical advice on good government from book three onwards. As stated before, he did not dwell upon the childhood of the future prince and the need of a high-principled education. The first, rather short book, gives a general approach of the main assets of civil life, virtus and prudentia. Virtue is divided into pietas (religiousness) and probitas (uprightness). The former can be distinguished into internal and external religiousness, sensus (belief) and cultus (worship) - more weight is attached to the former. Closely linked with belief is the attitude towards Fatum, which should be accepted, albeit not in a desperate way, ${ }^{20}$ whereas Conscientia is considered an appendage of worship. A bad conscience causes torment, whereas a good conscience assures a peaceful and harmonious life. After defining and shortly elaborating on Probitas, Lipsius passes to the second guide, Prudentia, which is divided into private and public wisdom. It is based on usus (experience from seeing or doing) and memoria (remembrance from hearing and reading). Lipsius prefers the former as a more difficult but more certain path towards wisdom. In a final chapter learning is recommended as a useful support for both Virtue and Wisdom.

In his second book Lipsius switches to government (imperium) with three main systems: monarchy, aristocracy, and democracy. Without further ado monarchy is presumed to be the best because it is the oldest form. It also stands closest to what is to be observed in nature. Moreover, it is the most rational option that a political entity should be ruled by one person, as a ship is steered by one captain. The alternative can only lead to chaos. In

19 In the introduction to his edition, Jan Waszink distinguishes two parts of three books each, a 'moral' and a 'practical' one, thus saddling himself with a complex construction, since 'the discussion of Prudentia starts already in book three' [about the prince's counsellors and ministers], setting apart book five as 'a more technical "handbook" on how to build up a standing army', before linking up book six, on civil wars, to the more 'political' argument of book four again. Cf. Waszink (ed.), Lipsius, Politica 81-82 and 199-200 (quoted): 'In the first three books Lipsius speaks in terms of the traditional princely virtues, and thus carves out for himself a traditional moral ethos which provides him with a basis of acceptability and credibility from which, in the last three books, he can proceed to reshape that traditional morality'. I rather prefer to keep to Lipsius's composition as expounded in the titles and the introduction of various chapters and collected in the aforementioned Ordo et Index librorum singillatim et capitum.

20 Lipsius had discussed Fatum and Necessitas at length in his De constantia, I, §17-21. These chapters raised controverse, as becomes clear from numerous non-Plantin editions and translations, were these chapters were often omitted.

\section{(C) 2013 Koninklijke Brill NV ISBN 978-90-04-25562-3}


the third chapter monarchy is defined as '(1) unius imperium, (2) moribus aut legibus delatum, (3) susceptum gestumque (4) parentium bono' ('the government by one, conferred in accordance with law and custom, and taken up and executed in order to serve the well-being of the subjects'). ${ }^{21}$

In the next chapters the four elements of this definition are examined one by one. With regard to the first part, 'unius imperium', Lipsius raises the question whether the ruler should be a man or a woman. Both are possible, but nature and reason clearly prefer a man. The former is confirmed by a quotation from Aristotle (Politics 1259b), the latter by pointing out that God gave women a heart full of deceit (confirmed by Seneca, Octavia 868-869) and created them with a total lack of constancy (confirmed by Propertius II, 25, 22) and poor judgement (confirmed by Tacitus, Annals $\mathrm{XV}, 54)$. Women cannot, however, be entirely excluded from government, as is proved with a reference to Britons and Germans. In the second part of his definition, 'moribus aut legibus delatum', Lipsius states that there are only two legitimate ways to the throne, either by election or by succession. Unlike Erasmus at the beginning of his Institutio Principis Christiani, no immediate preference is shown. Succession prevents turmoil and is more secure; election, on the other hand, will find the better man and is a mark of freedom. In the third element, 'susceptum gestumque', it is pointed out that governors often start in a laudable way, but that they should continue to live up to the expectations throughout their reign. The final part of the definition, 'parentium bono', must be realized in both an external way, by bestowing benefits on the populace, and an internal way, by a virtuous and exemplary behaviour. To reach his salutary goal, the welfare of his people, the prince must follow the two guides defined and described in book one, namely virtus, which will reveal itself in his way of living, and prudentia, manifesting itself in his actions.

The remaining part of book two is devoted to virtus, which is necessary for the prince himself because of decorum, reputation, and the stability it brings in his reign. It must also be instilled in his subjects, as a guarantee of a sound and lasting community. The citizens will become virtuous through laws (to be discussed later) and the prince's example. Hence Justice and Clemency are defined and discussed as the main qualities needed in a good ruler. Justice must be dispensed in an impartial and moderate way, without heaping up laws or encouraging lawsuits. Clemency will make the ruler beloved and illustrious, and assures his

21 Translation quoted from Waszink (ed.), Lipsius, Politica 301.

(C) 2013 Koninklijke Brill NV ISBN 978-90-04-25562-3 
position. This virtue too must be used with moderation; it might even slightly depart from justice, as long as it does not dissolve the strength of power. Reliability and Modesty are discussed as appendages of Justice and Clemency, respectively. In Lipsius's eyes there can be no doubt that reliability is a cornerstone of society, hence his fierce attack against Machiavelli and his followers ('ab Etruria doctores novi'), 'who poison the ears of Princes and exhort them to forget about all that is right and honourable, so long as they pursue power. Who serve up that long-since buried view that Justice may be violated for the sake of ruling'.22 Modesty must be instilled in both the mind and the actions of a prince. As his appearance is important as well, he should take care of his speech, which has to be serious and sober, and he must avoid extravagance in his apparel. This brings Lipsius to another asset, Majesty, and how it can be acquired. To conclude this list of virtues, a number of less prominent virtues are mentioned scatteredly and briefly: the ruler is recommended to be generous and chaste, to avoid anger and be scornful of slander. He must give heed to his reputation, both at the present time and with regard to posterity, and promote and support learning, 'which presently languishes. Because when the rewards for study are removed, study itself will perish'. ${ }^{23}$

\section{On Statecraft}

\subsection{Erasmus}

With chapter two Erasmus begins the practical advice directed to the adult sovereign. First of all, the prince is to learn how to distinguish between idle or opportunist flattery, and well meaning friendship, since good advice is crucial for good government. Flattery is not limited to excessive praise, but can also reveal itself in honorary statues, paintings, literature, and titles. $^{24}$ In the next sections Erasmus focuses on a smooth government in peace-time, for, as he states in the opening lines of chapter three,

Iam tametsi prisci scriptores universam administrandae reipublicae rationem in duplices artes secuerunt, pacis et belli, et prior et praecipua cura debet esse principis instituendi in his rationibus, quae ad pacis tempora

22 Translation taken over from Waszink (ed.), Lipsius, Politica 333; 335. The italics are quotes from Cicero, On Duties, III, 82; and Euripides, Phoenician Women 524-525 respectively.

23 Translation taken over from Waszink (ed.), Lipsius, Politica 345. Lipsius is quoting Tacitus, Annals XI, 7.

${ }^{24}$ For this chapter, Erasmus is indebted to Plutarch's essay How to tell a Flatterer from a Friend (Moralia $48 \mathrm{e}-74 \mathrm{e})$.

\section{(c) 2013 Koninklijke Brill NV ISBN 978-90-04-25562-3}


sapienter moderanda pertinent, quibus hoc pro virili conandum est, ne belli muniis unquam sit opus.

Although ancient writers divided the whole theory of statecraft into two sets of skills, those of peace and of war, our first and foremost concern must be for training the prince in the skills relevant to wise administration in time of peace, because with them he must strive to his utmost: that the devices of war may never be needed. ${ }^{25}$

A good understanding between the people and its leader is crucial for successful government. The prince is recommended to make himself familiar with his country by studying geography and history, and by making frequent tours throughout his realm. He will feel the same love towards his country as a farmer towards his lands or a father towards his family. Hence Erasmus's preference for a sovereign who was born and brought up among the people he is going to rule. He should also choose his spouse at home or close to home, instead of in distant countries. He must do his utmost to earn the unremitting affection of his subjects, but without losing any of his authority, in the way the Lord provokes the love and awe of mankind through his benefices. In his private life the prince should persist in a sober lifestyle; in public appearances he must exude authority and dignity. One of his principal concerns must be about a proper education in both private and public schools, to help his future citizens to grow up into good Christians and honest persons. In the next chapters Erasmus points out that moderation in the levy of revenues and taxes is crucial to gain the sympathy and the awe of one's citizens.

Hoc potius studendum et in hoc excogitandae rationes, ut quam potest minimum exigatur a populo. Commodissima fuerit augendi vectigalis ratio, si princeps sumptus supervacaneos amputarit, si ministeria ociosa reiecerit, si bella et his simillimas peregrinationes vitaverit, si officiorum rapacitatem cohibuerit et si magis studeat recte administrandae ditioni suae quam propagandae.

Rather should his efforts and deliberations be directed to this end, that he spend time away from his people as little as possible should be extracted from the people. The most suitable way of increasing revenue would be for the prince to abolish superfluous expenditure, to do away with redundant offices, to avoid wars and foreign tours (which are very like wars), to check the rapacity of public office, and to pay more attention to the just administration of his territory than to its expansion. ${ }^{26}$

25 Cf. $A S D$ IV.1, 182, l. 524-528; translation Cheshire and Heath, CWE 27, 253.

26 Cf. $A S D$ IV.1, 189, l. 742-746; translation Cheshire and Heath, CWE 27, 260.

\section{(C) 2013 Koninklijke Brill NV ISBN 978-90-04-25562-3}


Erasmus is well aware that it is impossible to dispense with taxes completely, so he recommends the prince to levy them in such way that the rich take the larger part of the burden, for instance by imposing levies on imported luxury products, which are purchased by the rich only. On the other hand, as little taxes as possible should be extracted from wheat, bread, beer, wine, or clothes, and other necessities of life, which the poor need as well. The prince is warned to be honest in the coinage of money. Moreover, he must adopt an attitude of generosity towards his subjects in an impartial way and 'this should be the reward of virtue, not the result of a whim'. He should also be forthcoming towards foreigners and make sure that no harm befalls them.

A good and upright prince is also some kind of embodiment of the laws. The laws he is enacting should not be limited to punishing misdemeanours, but must prevent the committing of offences and promise rewards for public services. Any suspicion of profit seeking or favouritism should be avoided and 'everything should be related to an ideal standard of honour and to the public interest'. The prince must surround himself with competent and conscious ministers and counsellors, carefully selected not for outward appearances, but rather for their moral assets. In concluding treaties as well he must always have in mind the prosperity of his country and strive for peace. The happiness and well-being of his subjects must prevail over the expansion of his country. Although marriage alliances are partly a private affair, it is preferable to choose a partner within the boundaries of his realm or in a neighbouring kingdom. In the final chapters Erasmus argues strongly in favour of peace, a theme that keeps cropping up in his works and his correspondence. Arms must only be taken up after careful deliberation, when all other attempts have failed, for all wars bring about a tide of calamities and misery for both the enemy and the citizens. Moreover, armed conflicts soon tend to escalate and leave everincreasing marks of bloodshed and violence. Some years before, Erasmus had made a similar plea in favour of peace in one of his longest and most famous adages, "Dulce bellum inexpertis" ("War is sweet for those who have not tried it", Adage IV. 1, 1), and he would hark back to this theme in the Querela pacis (Complaint of Peace, published in 1517).

\subsection{Lipsius}

With the third book of his Politica, Lipsius turns to the second pillar of civil life, prudentia, which is indispensable for good government, for without it strength and wealth are useless. The three are to be intermingled, but Prudence prevails. Prudence is twofold, that of the prince himself and

\section{(C) 2013 Koninklijke Brill NV ISBN 978-90-04-25562-3}


that of others. As it is rare, even impossible that a ruler has sufficient wisdom of his own, he must seek helpers, whom he has to select with utmost care. Next Lipsius distinguishes two categories, counsellors and ministers, both to be defined and their usefulness explained.

Counsellors will help mostly with their words and their thinking. Their chief assets are probitas (integrity) and peritia rerum (experience), their main duty is offering sound advice, a task advanced by piety, independency, constancy, modesty, and discretion, but thwarted by arrogance, disagreement, emotions, greed, self-assurance and rashness. Then the author focuses on the prince again and how he must behave in hearing counsel: he should deliberate well in advance, listen carefully, without prejudice or obstinacy. He should hide his own views and encourage his helpers to speak freely. He should not oppose Fate. Secret advice and consultations of courtiers are to be rejected.

Ministers are chosen for specific tasks, either in public or in private. The latter category, that of men who render services in the palace, is of no further importance; the former assist the prince with ruling or in administration and are allotted specific tasks, matching their talents and skills. They should be of good descendancy, with the exception of extraordinary virtuous individuals, and have an unblemished reputation. Lower officials must be subservient, obliging, and courageous; more important ones efficient, quick and modest, not haughty. They must show endurance and caution, and leave the credits for their achievements to the prince. They should also be aware that authority in court is unstable.

With book four Lipsius switches to what is called 'propria prudentia', statecraft, or prudence which the prince himself is expected to show and which can have consequences for strengthening or weakening the realm. As it covers a wide area, it is uncertain and veiled, hence Lipsius does not claim to fully discuss it. Distinction must be made between prudence in civil and in military life. The former, which is the subject of book four, is divided into human and divine matters. As usual, Lipsius begins by explaining the second element, an aspect which was never really under discussion with Erasmus, who only kept emphasizing the idea that an excellent ruler should follow God's example as closely as possible. Of course, when Erasmus wrote his Institutio Principis Christiani, Luther had not yet nailed his theses on the door of the Castle Church in Wittenberg, thus initiating the Protestant Reformation. Conversely, Lipsius's time had witnessed years of bloodshed and the most cruel atrocities in the name of true Faith all over what had been Catholic Europe in Erasmus's days. 
According to Lipsius, religion is an important part of the prince's task: he must preserve unity of religion and defend it. He is utterly convinced of the principle cuius regio, illius religio, as it was developed in the Peace of Augsburg (1555): it is the prince's duty to decide in this matter and make his populace concede. Nevertheless, Lipsius formulated his ideas in a general way, without suggesting that the sovereign should ipso facto opt for Catholicism or without the merest hint of partiality, thus provoking the ire of Dirck Volckertsz. Coornhert, among others, who insisted that Lipsius should speak out on this matter. Public dissent - i. e. citizens who stand up for their deviant opinion on God and religion, and encourage others to follow them - should not go unpunished, lest the prince be harmed because of them. This is especially the case if they are causing disorder. There is no place for clemency here, which is confirmed by the notorious reference to Cicero: 'Ure, seca, ut membrorum potius aliquod quam totum corpus intereat' ('Burn, cut, in order that some member perish rather than the whole body'). ${ }^{27}$ The phrase was, in fact, a figure of speech, borrowed from medical language, and referring to physicians who have recourse to amputation or cauterisation in order to heal the patient. Yet, it provoked a fierce reaction from Coornhert, who claimed that Lipsius was defending the Spanish inquisition with its appalling practices of torture and sending people to the stake. Only when suppressing troublemakers might cause major turmoil (here Lipsius was clearly referring to contemporary events) should the prince postpone his actions, as is confirmed by Livy, XXII, 18, 9: 'for physicians too sometimes achieve more by inactivity than by taking action'. He has to consider every occurrence separately and decide whether it is not better to close an eye, rather than provoking misdemeanour and even turmoil by untimely reactions. Individuals, however, who were living quietly and keeping their ideas to themselves, should not be punished, nor should they be searched for too much and submitted to thorough questioning. Prosecution would only lead to dissimulation; it was better to convince them by teaching and guiding ('docendi et ducendi') for, as Bernardus said,28 'Fides suadenda est, not imperanda' ('Faith must be induced by persuasion, not by command'). It comes as no surprise that these chapters in particular caused the Politica to be put on Sixtus V's index of forbidden books, at least provisionally,

27 Cf. Cicero, Philippics 8, 5, 15: 'In corpore si quid eiusmodi est, quod relinquo corpori noceat, id uri secarique patimur, ut membrum aliquod potius quam totum corpus intereat. Sic in rei publicae corpore ut totum salvum sit, quicquid est pestiferum amputetur'.

28 Sermones super Cantica Canticorum 66, 12.

\section{(C) 2013 Koninklijke Brill NV ISBN 978-90-04-25562-3}


'donec corrigatur' and were, indeed, corrected heavily for the expurgated edition from 1596 onwards. ${ }^{29}$

In chapter five, Lipsius passes to statecraft in wordly affairs, which will profit by understanding the nature of one's citizens and of kingship. Yet whereas Erasmus encouraged the prince to become thoroughly acquainted with his subjects in his third chapter, Lipsius focuses entirely on the shortcomings of the great mass of a country's citizens and that of neighbouring countries as well, since the sovereign often has to deal with them. Inquiry, practical experience, and reading books will teach the prince that the masses, and even mankind in general, are fickle, affected by emotions, devoid of judgement, jealous, suspicious, credulous, and hot-tempered, indifferent to the common weal. They are valiant in words only, prone to chaos and excesses. The humanist's characterisation of monarchy in chapter six is not very encouraging either: it is liable to fate, hatred, fear, rivalry, hazards from lack of self-control or conspiracies.

In the chapters seven to nine, Lipsius expounds on the need for practical strength and princely virtue as beneficent factors for a stable and thriving realm. A sovereign needs soldiers as body-guards and to form a (small) standing army; he also needs strongholds, be it castles or colonies. Appropriate virtuous behaviour will prove even more salutary, for it will result in goodwill from his subjects and authority. The former is provoked by generosity, a moderate indulgency, and benefactions. Authority is based on awe and fear. Conversely, violence and princely misbehaviour will cause kingdoms to be overthrown, as he explains in a matching set of three chapters. Violence leads to conspiracies and treason; princely vices such as cruelty, greed, and obstinacy will cause hatred which is to be avoided at all costs, or contempt. Hence the prince should shun and abhor harsh punishment, greedy taxation, and obduracy, nor should he be too lenient or wavering.

29 Cf. Reusch F.H., Der Index der Verbotenen Bücher. Ein Beitrag zur Kirchen- und Literaturgeschichte, 2 vols. (Bonn: $1883^{-1885}$ ) 501-531 (on the Index of Sixtus V) and $53^{2-538}$ (on its revised version by Clement VIII). See on this matter Waszink (ed.), Lipsius, Politica 120-124. The reaction of Spanish bookcensors on the Politica (or its Spanish translation by Bernardino de Mendoza, Los seys libros de las Políticas de Bernardino de Mendoza (Madrid: 16o4) is discussed by Pérez A.D., "La recepción española de las Políticas de Lipsio en el siglo XVII: la traducción castellana de Bernardino de Mendoza (Madrid: 1604) y la expurgación de la obra en los índices inquisitoriales", in De Landtsheer J. - Delsaerdt P. (eds.), Iam illustravit omnia. Justus Lipsius als lievelingsauteur van het Plantijnse Huis, Gulden Passer 84 (Antwerp: 2006) 103-126.

\section{(C) 2013 Koninklijke Brill NV ISBN 978-90-04-25562-3}


To conclude his views on statecraft in worldly affairs Lipsius dwells upon the use of deceit, in which he discerns three categories: light (distrust, dissimulation), middle (corruption, deception), and grave (breach of faith, injustice). In his eyes the lighter type can be accepted and even recommended, the middle one tolerated, whereas the third kind is definitely forbidden. In fact, he adds, corruption, breach of faith, and injustice are also forbidden by Scripture.

Books five and six as well show how much Lipsius was affected by the often atrocious contemporary events, which he had either lived through or had heard and read about. In this section of the Politica he expounds on military prudence, which is needed in two types of war, first and foremost against other countries (book five), but unfortunately also in cases of civil discord (book six). It is nevertheless indispensible for the defence and the safeguard of a realm. Before coming to the point, Lipsius strongly asserts that no war should ever be started for unjust reasons. Moreover, to quote Waszink's summing up of the arguments: 'A just war must be declared by the prince himself, either to defend himself and others who are in danger, or to invade for the sake of revenge, or invade savages'.$^{30}$ Lipsius, as well as Erasmus in the final chapter of his Institutio Principis Christiani, "De bello suscipiendo" ("On Starting War"), 31 strongly asserts that before taking up arms, every possible legal solution or negotiation should be attempted. A war must never be started rashly, but only after careful planning. The prince should also keep in mind its dire consequences for winners and losers alike, and the profits of a possible victory will never compensate for the costs, the bloodshed, the physical and mental suffering, and the material losses.

In the next chapters of the fifth book Lipsius discusses at length how troops should be carefully recruited and the need of discipline, which is imperative (chapters 7-13). Before entering into this discussion he makes a digression, lashing out against the armies of his time, which he brands as bands of robbers and cowards, the scum of their towns, averse to any form of discipline. ${ }^{32}$ The prince is recommended to have a rather modest stand-

30 Cf. Waszink (ed.), Lipsius, Politica 210.

31 Cf. $A S D$ IV.1, 213-219.

32 In fact, he also gave vent to similar remarks or complaints in his correspondence, see, e.g., ILE II, 850628 LE to his former student Theodorus Leeuwius (1548-1596), one of his former students and later councillor at the Court of Holland. [ILE II = Iusti Lipsi Epistolae, pars II: 1584-1587, ed. M.A. Nauwelaerts and S. Sué (Brussels: 1983)] This letter is discussed in De Landtsheer J., "L'évolution politique aux Pays-Bas du Nord après

\section{(C) 2013 Koninklijke Brill NV ISBN 978-90-04-25562-3}


ing army of some 6000 infantry and some 1200 cavalry (the numbers apply to a realm of medium size), but he should also be able to raise an auxiliary army of about 30,000 to 40,000 footmen recruited from men who normally live by other means. Native soldiers are preferable to mercenaries from abroad, for they will be cheaper, more loyal and obedient. ${ }^{33}$ In the chapter on discipline Lipsius makes reference to the army practice of the Romans, whose example should be followed. ${ }^{34} \mathrm{He}$ distinguishes four parts: training (with regard to the use of weapons, battle order, the long and often exhausting daily marches, and the tasks and duties involved in camp life), maintaining order in the camps and during marches, imposing restraints by all kinds of rules, and examples either by punishment or rewards. A reworked and much elaborated version of these chapters was published six years later as the fifth book of De militia Romana, on Roman army practice, conceived as a commentary to Polybius's Histories, VI, $19-42 .^{35}$ Lipsius not only intended this treatise as a general introduction to warfare for scholars focused on ancient history, but also hoped to provide the modern commanders-in-chief with some useful suggestions for the organisation of their own army and battles.

Chapters $14^{-17}$ deal with the commanders of higher and lower rank (with the warning that there should be only one general in a war, the souvereign), the importance of good strategy and planning, and the possible use of stratagems and cunning. Lipsius concludes his advice about waging war against other nations by giving his opinion on how a Prince

1584", in Laurence P. - Guillaumont F. (eds.), L'histoire dans l'épistolaire (Tours: 2011) [forthcoming].

33 Cf. the summary of Waszink (ed.), Lipsius, Politica 210-211. Erasmus does not warn explicitly against mercenaries in his Institutio, but he often severely criticizes them in his Colloquies and Adages.

34 At the beginning of the fifth book, Lipsius had pointed out that his familiarity with the ancient historians made up for his lack of practical experience and entitled him to speak with understanding and judgement.

35 Iusti Lipsi de militia Romana libri quinque. Commentarius ad Polybium. E parte prima historicae facis (Antwerp, Widow of Plantin and Johannes Moretus: 1595-1596). On the editio princeps and later editions, see $B B r$, vol. III, 1002-1005 (L-369-75). On this treatise, see De Landtsheer J., 'Justus Lipsius' De militia Romana: Polybius Revived, or How an Ancient Historian was turned into a Manual of Early Modern Warfare", in Enenkel K.A.E. - de Jong J.L. - De Landtsheer J. (eds.), Recreating Ancient History. Episodes from the Greek and Roman Past in the Arts and Literature of the Early Modern Period, Intersections. Yearbook for Early Modern Studies, 1 (Leiden-Boston-London: 2001) 101-122. Once returned to the Spanish Low Countries (August 1592), Lipsius was time and again confronted with plundering and mutinying soldiers, who exacted levies under threat all over the countryside south of Brussels and Leuven, where he had inherited some estates from his parents, hence the exceptional length of the fifth book of De militia.

\section{(C) 2013 Koninklijke Brill NV ISBN 978-90-04-25562-3}


should conduct himself to his advantage and honour either in victory or defeat, and an urgent exhortation to agree upon a peace that is honest and honourable for both sides (chapters 18-20).

With the much shorter book six, on civil war, Lipsius discusses an issue, which is absent in Erasmus's Institutio Principis Christiani. It is defined as 'a war in which subjects take up arms against their sovereign or among each other' and characterized as an appalling plague and 'a sea of disasters' for any country. ${ }^{36}$ With the former part of the definition, Lipsius is obviously referring to the rebellion within the Low Countries against King Philip II, which had been going on for more than twenty years when the Politica appeared. ${ }^{37}$ With the latter part he is reminding his readership of the religious wars among Catholics and Huguenots in France, which would break out with great fierceness again after the murder of Henry III $(\dagger 1$ August 1589), when his Politica was already in press. In chapters $2-5$ the causes of civil war are defined and explained and possible solutions suggested. Next follows a rather long excursion on the question of whether a good man should take part in civil war. After giving arguments and examples of both alternatives, Lipsius concludes that one should always opt for peace and avoid civil war. Yet, a public person, involved in politics, cannot merely limit his commitment to peace time, but has to devote himself to his country and might thus become involved in the conflict. A common citizen, however, has no reason whatsoever to choose sides and to involve himself suddenly in strife. The final chapter, on ending civil war, advises to accept any peace, even if it seems unreliable. The delay gives time and may cause spirits to settle down. It also gives an opportunity to send the leaders of a rebellion away, to start a war abroad in order to strengthen internal concord, and soothe spirits by showing clemency. The Politica ends with a prayer to God for peaceful and wise sovereigns, thus matching the final address of Erasmus to Charles V in the Institutio Principis Christiani.

\footnotetext{
36 Cf. Politica, VI, $\S$ 1: 'Arma subditorum in Principem mota, aut inter sese' (Lipsius, Politica ed. Waszink 666. 'Mare calamitatum' as Lipsius describes it (ibidem), is a variant of Adage I, 3, 28 "mare malorum").

37 Until well in the seventeenth century documents from the Spanish Netherlands usually consider the endless campaigns against the Northern Provinces as a civic war. This is especially clear in ILE VIII, $950202 \mathrm{~S}$, a letter in which Lipsius gives his opinion about the policy the Spanish king should adopt towards France, England, and the Northern Provinces. [ILE VIII = Iusti Lipsi Epistolae, pars VIII: 1595, ed. J. De Landtsheer (Brussels: 2004)] But in numerous other letters as well he often deplores the stubbornness of the 'rebels in the North' who refuse obediency to their legitimate king.
}

\section{(C) 2013 Koninklijke Brill NV ISBN 978-90-04-25562-3}




\section{Conclusion}

At the end of this article there remains the question of dependency: did Lipsius know Erasmus's Institutio principis, and if so, in what way did it influence his Politica. As already pointed out by Jan Waszink, 'the name of Lipsius' great predecessor is never mentioned in the Politica', ${ }^{38}$ nor is the Institutio principis listed in the catalogue of Lipsius's books drawn up in the days following his death. ${ }^{39}$ However, this does not mean that the treatise was unknown to the Leiden humanist. The main reason for this remarkable absence of both the author's name in the Politica and the book in Lipsius's library is undoubtedly the ambiguous status of Erasmus in Catholic areas. In 1559 Pope Paul IV had consigned Erasmus's whole oeuvre to the Index librorum prohibitorum and although his successor, Pius IV, had mitigated this decision in his so called Index of the Tridentine Council (1564) by agreeing that most of the works (although not the Encomium Moriae and the Colloquia) could be read after being approved by Catholic theologians, this still meant that numerous passages from the Institutio principis were censured [Fig. 5]. ${ }^{40}$ Lipsius was still living in Leiden when he wrote his Politica, hence he did not have to worry about the copy of the Institutio he used, but once he had decided to return to the Spanish Netherlands, he had to be careful about the books he kept in his library. Moreover, since his works aimed at a readership all over Europe, he had to be cautious not to refer overtly or frequently to sources which were might raise suspicion in Catholic minds. Despite Pope Pius IV's revocation of his predecessor's decision, Erasmus was still persona non grata in Catholic circles and references to him would only have had a weakening effect on Lipsius's argumentation.

38 Cf. § 4.2.11, "The Politica and Erasmus", in Waszink (ed.), Lipsius, Politica 113.

39 Cf. its legalized copy in Leiden, University Library, ms. Lips. 59, which, together with Marcus de Schepper I am preparing for publication. This document, however, mentions a copy of Jean Bodin's Les six livres de la République (Paris, Jacques Du Puys: 1576) in its Latin translation published (Paris, Jacques Du Puys: 1586), cf. fol. 5r, book 9). Bodin's De re publica does not occur in the Politica either, although it is referred to in the correspondence.

40 Cf. Waszink (ed.), Lipsius, Politica 113, no. 113 and his reference to Vanautgaerde A., art. "Institutio principis", in Soly H. - Van de Wiele J., Carolus. Keizer Karel V 1500-1558 (Ghent: 1999) 204-205. This same rigorous restriction also concerned the Adages, in which Erasmus had already formulated the major part of his ideas about good government, which he afterwards gathered in the Institutio. Lipsius owned a copy of the "Tridentine" edition of the Adagia, largely prepared by Paulo Manuzio: his library catalogue mentions Adagiorum Des[iderii] Erasmi, [...] emendatae et secundum concilii Tridentini decretum expurgatae [...] (Paris, Nicolas Chesneau: 1571), cf. Leiden, Univ. Lib., ms. 59, fol. 4v, book 5 .

\section{(C) 2013 Koninklijke Brill NV ISBN 978-90-04-25562-3}




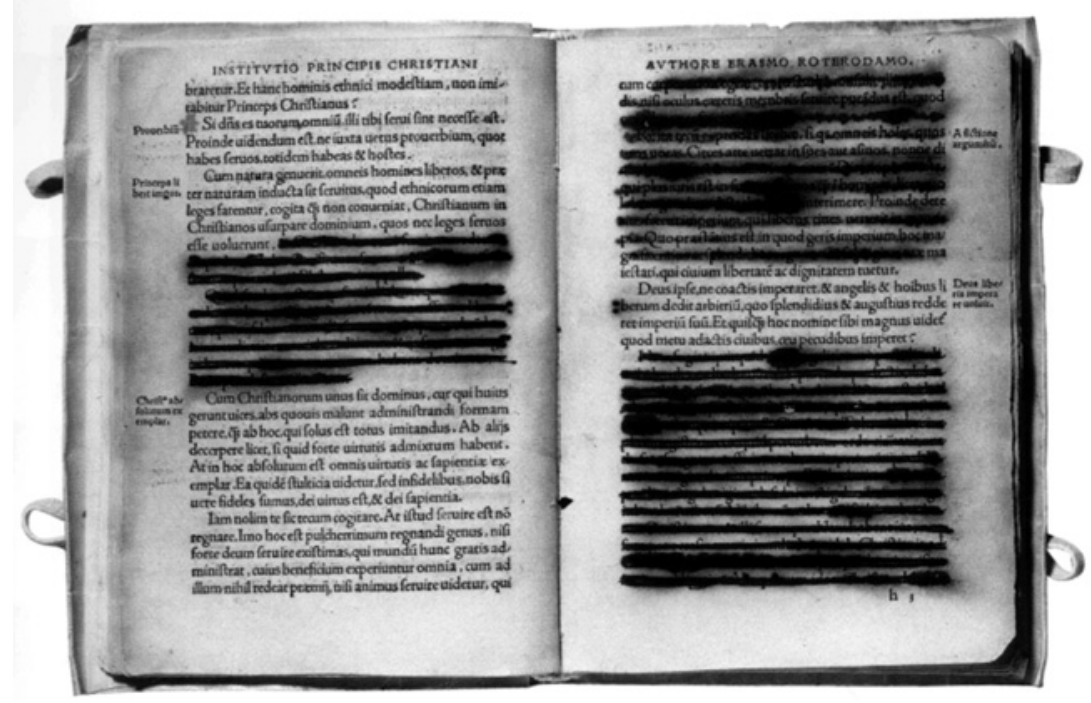

Figure 5. Censured pages of Erasmus, Institutio principis Christiani (Basle: Johann Froben, 1516). Anderlecht, Erasmushuis, Inv.nr. E 412.

Both Erasmus and Lipsius derived their portrait of an exemplary Prince from the political theories of Antiquity, although they expressed their ideas in a completely different way. They show their familiarity with a long line of classical authors and also with the Fathers. Historiographers in particular were a welcome source for Erasmus to enhance his ideas with either positive or negative examples. Lipsius would do the same some years later, in his Monita et exempla politica (Antwerp, Johannes Moretus: 1605), a work in which he systematically repeats the theories of books I and II of the Politica, illustrating each chapter with numerous anecdotes, either warnings or examples. In his Politica his profound knowledge of ancient literature is shown in an authoritative way by formulating his thoughts through a string of quotations, in which Tacitus plays the main part. Although he quotes a number of authors and works occurring in the Institutio ${ }^{41}$ and sometimes also in the Adages (in a rare case even adding the reference Adag[ia] in the margin, without specifying that he meant Erasmus's Adagia), he did not need Erasmus's work to become acquainted with the ideas vented in his primary sources, since

${ }^{41}$ It has been pointed out that Lipsius used Tacitus as his main source, an author not so frequently present in Erasmus's works, and not at all in the Institutio.

\section{(C) 2013 Koninklijke Brill NV ISBN 978-90-04-25562-3}


editions of authors from Antiquity, both Greek and Latin, had become easily available by the time he was writing his Politica. He surely browsed through the most important texts for his subject and, as always, excerpted an impressive collection of sententiae or loci communes.

Both treatises roughly follow the same structure, and this is the aspect that shows Erasmus's influence on Lipsius most clearly. As both authors interpret government as a hereditary monarchy, the Institutio and the Politica begin with an analysis of the assets a sovereign has in common with all virtuous and upright men (virtutes) before focusing on the specific tasks of a prince or, by extension, of every ruler (prudentia). The Institutio Principis Christiani, however, partly resuming the theories elaborated in De pueris instituendis, pays much attention to the pedagogical aspect of how an infant prince should be raised into an exemplary adult. Both authors warn their prince repeatedly to be wary of flatterers; they stress the importance of choosing capable, wise, and honest counsellors and aides who should be free to vent their opinion; they underline the importance of justice and clemency, and of reasonableness in collecting taxes and tolls. A sovereign's majesty and reputation is not determined by the length of his pedigree or his retinue, nor by expensive garments, sparkling gems, or a sumptuous way of life, but by his modesty and probity. A ruler should act towards his subjects as a father towards his children or a shepherd towards his flock. His only purpose should be the happiness and prosperity of all his subjects, rather than personal wealth and idle glory. The sovereign should always keep in mind that he is God's representative on earth; for Erasmus the pious king is ipso facto a Catholic king, whereas Lipsius, who is living in entirely different political and religious times and with part of his readership no longer adhering to the Catholic creed, does not specify to which religion the sovereign should adhere. They repeatedly launch urgent appeals in favour of a stable and honest peace, condemning warfare as an ultimate resort, when all other approaches have failed. As already mentioned in the analysis, the military aspect, with the organisation of the army in particular and its need for strong discipline, is discussed at length by Lipsius.

Contemporary history is present as well, although in quite a different way. Erasmus mentions events from his own time only occasionally and without elaborating, for example, his cautious criticism on the long and expensive travels of Charles's father, Philip the Fair, ( $\S 3$ and 4$)$ and his lengthy war against Gelderland $(\S 3)$, the conflict between James IV and his brother-in-law Henry VIII ( $(9)$, the spring tides repeatedly sweeping the coasts of Holland and Zeeland at the beginning of the sixteenth

\section{(C) 2013 Koninklijke Brill NV ISBN 978-90-04-25562-3}


century or the war between Pope Julius II and King Louis XII of France ( $\$ 10)$, and finally the increasing conflicts between Christians and Ottomans ( $(11)$. Lipsius, on the contrary, was much more strongly influenced than Erasmus by what was happening throughout Europe, ${ }^{42}$ as is also revealed in their correspondence. Not only did he show a much more marked interest in this subject than his predecessor; he was also living in an age that had witnessed the violence and bloodshed caused by religious or political dissensions throughout Europe, e.g. the infamous St Bartholomew's Day Massacre (24 August 1572). The turmoil in his native country had persuaded him to seek a safer harbour in the Northern Provinces, but after the Fall of Antwerp (August 1585) he became aware that the climate of religious tolerance was gradually changing, even provoking more and more tension between various Protestant creeds. Hence his insistence on unity of religion, as determined by the sovereign in book four, his urgent plea for a limited, efficient, and well-disciplined army in book five, and his warning against civil discord in book six.

Finally, Erasmus dedicated his Institutio Principis Christiani to Charles V and through him to all sovereigns and men of power. Lipsius, on the other hand, dedicated his treatise in a more general way to 'the Emperor, kings, and sovereigns'. Yet, one may wonder whether he too did not see his Politica as personal advice, viz., to Maurice of Nassau (1567-1625), who was studying in Leiden, when the murder of William the Silent on 10 July 1584 abruptly put an end to the life he had so much enjoyed. ${ }^{43}$ At that time Maurice still lacked his father's authority and the experience to keep the States in check and they eventually took over the government. Lipsius's correspondence of the next years indicates that he had little faith in a political system that entrusted power entirely to the States General. He was convinced that a state needed only one strong, capable leader, just as there should be only one captain of a ship or one general of an army. Hence his Politica might well have been an encouragement to his former student to stand up and demand the heritage he was entitled to [Fig. 6].

42 His correspondence clearly shows his insatiable interest in this aspect.

43 In ILE II, 840829 Maurice thanks Lipsius for his letter [of condolence, one can presume, since it has not been preserved] and expresses his sincere regret at no longer being able to follow his lectures. He also informs him that he has begun to study geometry and is starting to read Lipsius's De Constantia, which will mentally prepare him against the troubles in the Low Countries.

\section{(C) 2013 Koninklijke Brill NV ISBN 978-90-04-25562-3}




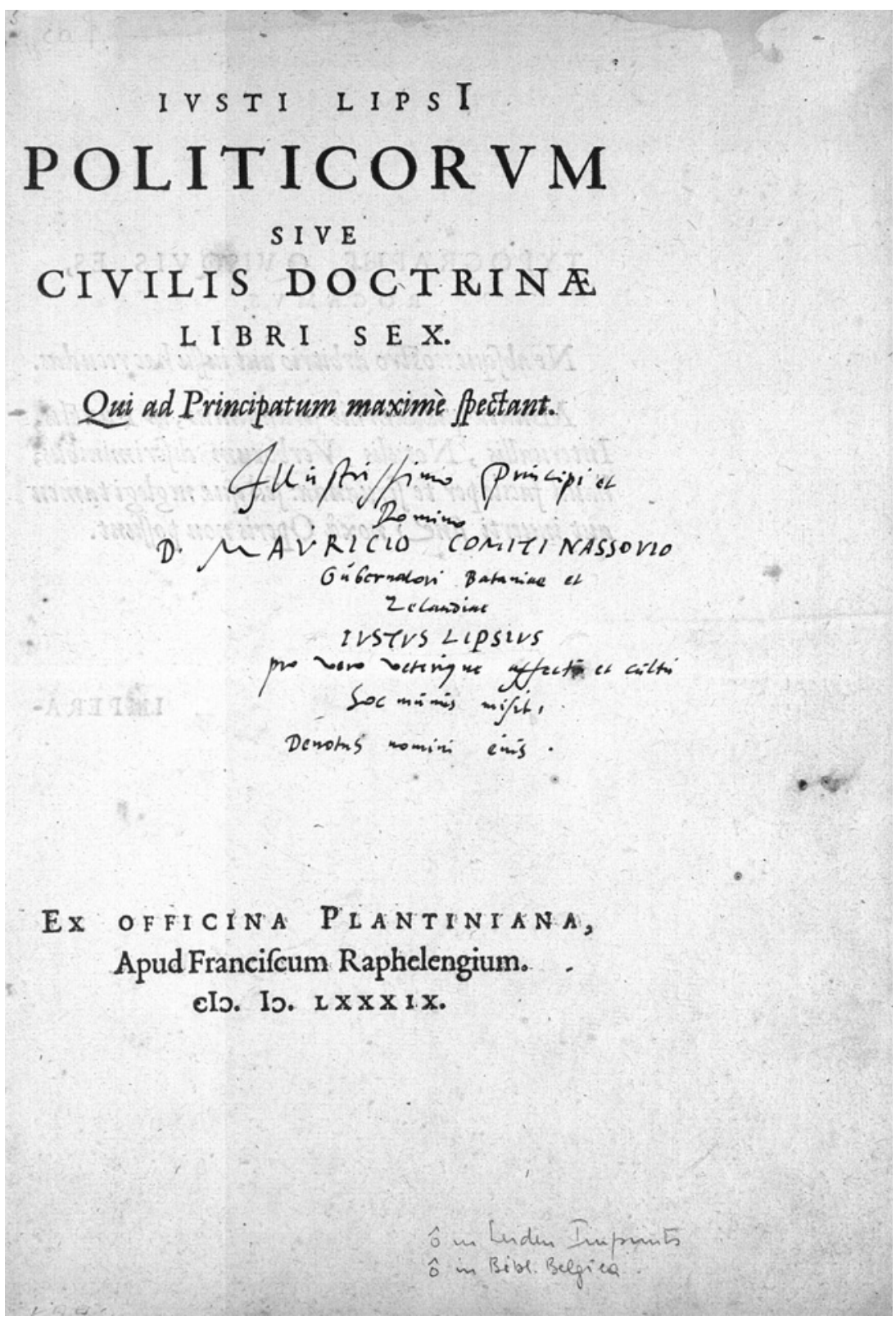

Figure 6. Lipsius's autograph dedication of a copy of the Politica to Maurice of Nassau on a loose title page without printer's mark: 'Illustrissimo Principi et Domino, D[omino] MaUricio, Comiti Nassovio, Gubernatori Bataviae et Zelandiae IUSTUS LIPSIUS pro vero veterique affectu et cultu hoc munus misit, devotus nomini eius'. Leuven, University Library, BRES, autographs (16th century).

(c) 2013 Koninklijke Brill NV ISBN 978-90-04-25562-3 


\section{Bibliography}

DÁvila Pérez A., "La recepción española de las Políticas de Lipsio en el siglo XVII: la traducción castellana de Bernardino de Mendoza (Madrid, 1604) y la expurgación de la obra en los índices inquisitoriales", in De Landtsheer J. - Delsaerdt P. (eds.), Iam illustravit omnia. Justus Lipsius als lievelingsauteur van het Plantijnse Huis, Gulden Passer 84 (Antwerp: 2006) 103-126.

Erasmus Desiderius, Institutio Principis Christiani, ed. O. Herding, ASD IV.1 (Amsterdam: 1974) 95-219.

-, The education of a Christian Prince, translated by Neil M. Cheshire and Michael J. Heath, CWE 27 (Toronto-Buffalo-London: 1986) 199-288. Reprinted together with Panegyric for Archduke Philip of Austria, translated by Lisa Jardine, Cambridge Texts in the History of Political Thought (Cambridge: 1997).

Iusti Lipsi Epistolae, ed. Gerlo A. - Nauwelaerts M. - Vervliet H. et al. (Brussels: 1978- ).

LANDTSHEER J. DE, "Justus Lipsius' De militia Romana: Polybius Revived, or How an Ancient Historian was turned into a Manual of Early Modern Warfare", in Enenkel K.A.E. de Jong J.L. - De Landtsheer J. (eds.), Recreating Ancient History. Episodes from the Greek and Roman Past in the Arts and Literature of the Early Modern Period, Intersections. Yearbook for Early Modern Studies 1 (Leiden - Boston - London: 2001) 101-122.

_ _ "An author and his Printer: Justus Lipsius and the Officina Plantiniana" Quaerendo 37 (2007) 10-29.

-, "Commentaries on Tacitus by Justus Lipsius. Their Editing and Printing History", in Henderson J.R. (ed.), The Unfolding of Words: Commentary in the Age of Erasmus (Toronto: 2012) 188-242.

—_, 'Juste Lipse et l'évolution politique aux Pays-Bas du Nord après 1584', in Guillaumont F. Laurence P. (eds.), La présence de l'histoire dans l'Epistolaire (Tours: 2012) 295-314.

LipsIUs Justus, Politicorum sive civilis doctrinae libri sex. Qui ad principatum maxime spectant (Leiden, Franciscus Raphelengius: 1589).

- , Politica. Six Books of Politics or Political Instruction. Politicorum sive Civilis Doctrinae libri sex, ed. J. Waszink (with translation and introduction), Bibliotheca Latinitatis Novae 5 (Assen: 2004).

Moss, A., "Vision fragmentée et unitaire: les "Politiques" et les recueils de lieux communs", in Mouchel C. (ed.), Juste Lipse (1547-1606) en son temps. Actes du colloque de Strasbourg, 1994, Colloques, congrès et conférences sur la Renaissance 6 (Paris: 1996) 471-478.

Reusch, F.H., Der Index der Verbotenen Bücher. Ein Beitrag zur Kirchen- und Literaturgeschichte, 2 vols. (Bonn: 1883-1885).

\section{(C) 2013 Koninklijke Brill NV ISBN 978-90-04-25562-3}

